\title{
EFFECT OF HOME PHYSIOTHERAPY ON BALANCE AND DYNAMIC AS WELL AS KINEMATIC MOVEMENT CHARACTERISTICS OF THE DOMINANT HAND FOR PEOPLE WITH PARKINSON'S DISEASE
}

\author{
Dalia Mickevičienè ${ }^{1}$, Indrè Skirmantaitè $\dot{e}^{1,2}$, Albertas Skurvydas ${ }^{1}$, \\ Diana Karanauskiené ${ }^{1,}$ Aiva Karpavičiené ${ }^{1}$ \\ Lithuanian Sports University', Kaunas, Lithuania \\ Mykolas Romeris University², Vilnius, Lithuania
}

\begin{abstract}
Research background and hypothesis. Parkinson's disease (PD) is a disease of the elderly, characterized by motor symptoms (resting tremor, bradykinesia, rigidity, and postural instability) when the extrapyramidal system lacks dopamine. Studies have shown that physiotherapy together with the usual medication used to treat PD can slow down the increasing immobility.

Research aim was to assess the effect of home physiotherapy on balance and dynamic as well as kinematic movement characteristics of the dominant hand for people with Parkinson's disease.

Research methods. Research group consisted of 8 patients with PD, stage 1-2 of the disease, the symptoms of which were expressed on the right hand. The study was conducted using Fullerton balance test and the human arm and leg movement Dynamic Parameter Analyser DPA-1.

Research results. Balance as well as kinematic and dynamic characteristics of movements for patients with PD statistically significantly improved $(\mathrm{p}<0.05)$ after the physiotherapy exercise cycle at home.

Discussion and conclusions. After physiotherapy, coordination of the dominant hand for patients with PD significantly improved: reaction time became shorter, maximum and average task speed increased, balance improved statistically significantly. The results showed that physiotherapy at home was an effective and reliable way for patients with PD to train their balance as well as kinematic and dynamic characteristics of their movements.
\end{abstract}

Keywords: physiotherapy, Parkinson’s disease, reaction time.

\section{INTRODUCTION}

$\mathrm{P}$ arkinson's disease (PD) is a chronic progressive neurodegenerative disease that begins due to dopamine deficiency in the extrapyramidal system and manifests itself by resting tremor, bradykinesia, rigidity and postural instability (Weintraub et al., 2008). Postural instability is a major risk factor for falls, which may reduce the patient's individual self-esteem and affect the quality of life (Wulf et al., 2009).

$\mathrm{PD}$ is the second most common chronic neurodegenerative disease after Alzheimer's disease. Its epidemiology characteristics vary among countries. This disease is prevalent worldwide in all ethnic groups (Danusevičienè, Zibalaite, 2010).
The causes of Parkinson's disease are not entirely known. The most important risk factor for PD is age (Weintraub et al., 2008).

The main neurochemical defect that causes the PD phenomena is pronounced deficiency of dopamine in the striatum system because of salvaged dopaminergic neurons in substantia nigra (pars compacta) (Burton et al., 2011). In the absence of dopamine, metabolic product of neurons which regulates movements, the main symptoms of Parkinson's disease develop (Kazlauskas, 2009). Clinically, Parkinson's disease is characterized by the triad of symptoms: tremor, bradykinesia, rigidity (Reinshagen, 2009). 
Research hypothesis: balance and dynamic as well as kinematic movement characteristics of the dominant hand for people with Parkinson's disease will improve after the home physiotherapy exercise cycle.

Research aim was to assess the effect of home physiotherapy on balance and dynamic as well as kinematic movement characteristics of the dominant hand for people with Parkinson's disease.

\section{RESEARCH METHODS}

Research was carried out in accordance with the principles of the Declaration of Helsinki, concerning ethics of the experimentation with humans. The study was conducted in the LAPE Laboratory of Human Motorics using human arm and leg movement Dynamic Parameter Analyser DPA-1, and Fullerton's balance test.

The study included a total of eight subjects: 4 men and 4 women. According to the modified Hoehn and Yahr stage scale, the symptoms of persons with stage 1-2 of Parkinson's disease are more pronounced on the right side, and the dominant hand is right. The age of the subjects was $65.63 \pm 7.42 \mathrm{~m}$, weight $74.20 \pm 10.83 \mathrm{~kg}$, height $170.80 \pm 5.89 \mathrm{~cm}$.

Persons who, besides PD, had underlying serious illnesses, disturbing movements or causing disability and significantly worsening the quality of life (stroke, severe osteoarthritis, a condition after arthroplasty, rheumatoid arthritis) were excluded from the research. The subjects were familiarized with the study objectives, methods, procedures and possible inconveniences. They were tested two times - before and after physiotherapy. After the evaluation of balance, reaction speed, movement accuracy, a 4-week course of treatment was started. Physiotherapy treatments took place at home of each subject four times a week for one hour. Every patient received 16 procedures. During the procedures, constant rhythmic auditory stimulation was carried out - commands, clapping, counting. Metronome and music were used in the procedures as well.

For balance we applied The Activities-specific Balance Confidence (ABC) Scale. Patients filled in this scale independently. The scale consists of 16 questions, the answer can be estimated from 1 to 10 ( 1 - completely do not trust, 10 - have full confidence). Subjects select a score that most closely matches their confidence in their balance.

DPA-1 device allows identification of reaction time, movement dynamic (strength, power) and kinematic (amplitude, velocity, acceleration) characteristics.
During the investigation the subjects were sitting in a special chair at the table, with a DPA-1 attached on it. Their back was straight and resting on the chair back, both arms were bent at the elbow joint angle of $90^{\circ}$ so that the upper arms were in contact with the sides of the forearms - based on the DPA-1 support plate. DPA-1 chair position was adjusted so that the subject sat comfortably taking the standardized position. The distance from the computer screen to the subject's eye was $\sim 0.7 \mathrm{~m}$.

Subjects performed the task with the right hand. According to a pre-defined task, the target a red circle $0,007 \mathrm{~m}$ in diameter - appeared on the screen at the set time. The distance from the starting area to the target is $0.16 \mathrm{~m}$. Hand movement path is reproduced identically on a computer screen. For each task, the subject puts a handle symbol $0.0035 \mathrm{~m}$ in diameter on a computer screen in the start zone (the centre of a green circle $0.01 \mathrm{~m}$ diameter). The program generates an alternating audible signal every $1-3$ and the subject has to respond by pushing the device handle to the target in the same place on a computer screen. The measurement cycle is finished when the handle symbol circle hits the target. Information about the task carried out is stored in the computer memory, which is then transferred to Microsoft Excel.

The subjects had to perform three tasks: a) to respond to the audible signal and push the device handle (a simple task), b) to respond as soon as possible (a simple task), c) to respond as soon as possible and as accurately as possible to hit the target on the computer screen (complex task). After explaining the task, the subjects were allowed to perform three trials, the results of which were not recorded. The subjects performed five sets of 20 repetitions. The interval between the sets was $2 \mathrm{~min}$, a set of repetitions was performed continuously and the maximal and average movement speed of the right hand, reaction time and the path of movement were recorded. After each repetition the subject could see their score on a computer screen. They were motivated to perform the task quickly and accurately.

Research data analysis was performed using SPSS 17.0 software package. Evaluating the research data, arithmetic average values $(\bar{x})$ of the researched indices were calculated, as well as the average standard deviation (s), the coefficient of variance (\% VA), Pearson's correlation coefficient (r). Twofactor analysis of variance was used to assess the significance of the results of different factors. The difference was statistically significant at $\mathrm{p}<0.05$. 


\section{RESEARCH RESULTS}

The analysis of the results showed that the application of physiotherapy for 4 weeks in patients with Parkinson's disease resulted in statistically significant differences between the registered parameters at the end of the study were compared to the results before the study: reaction time (Figure 1), average speed (Figure 2), maximum speed (Figure 3) and balance (Figure 4).
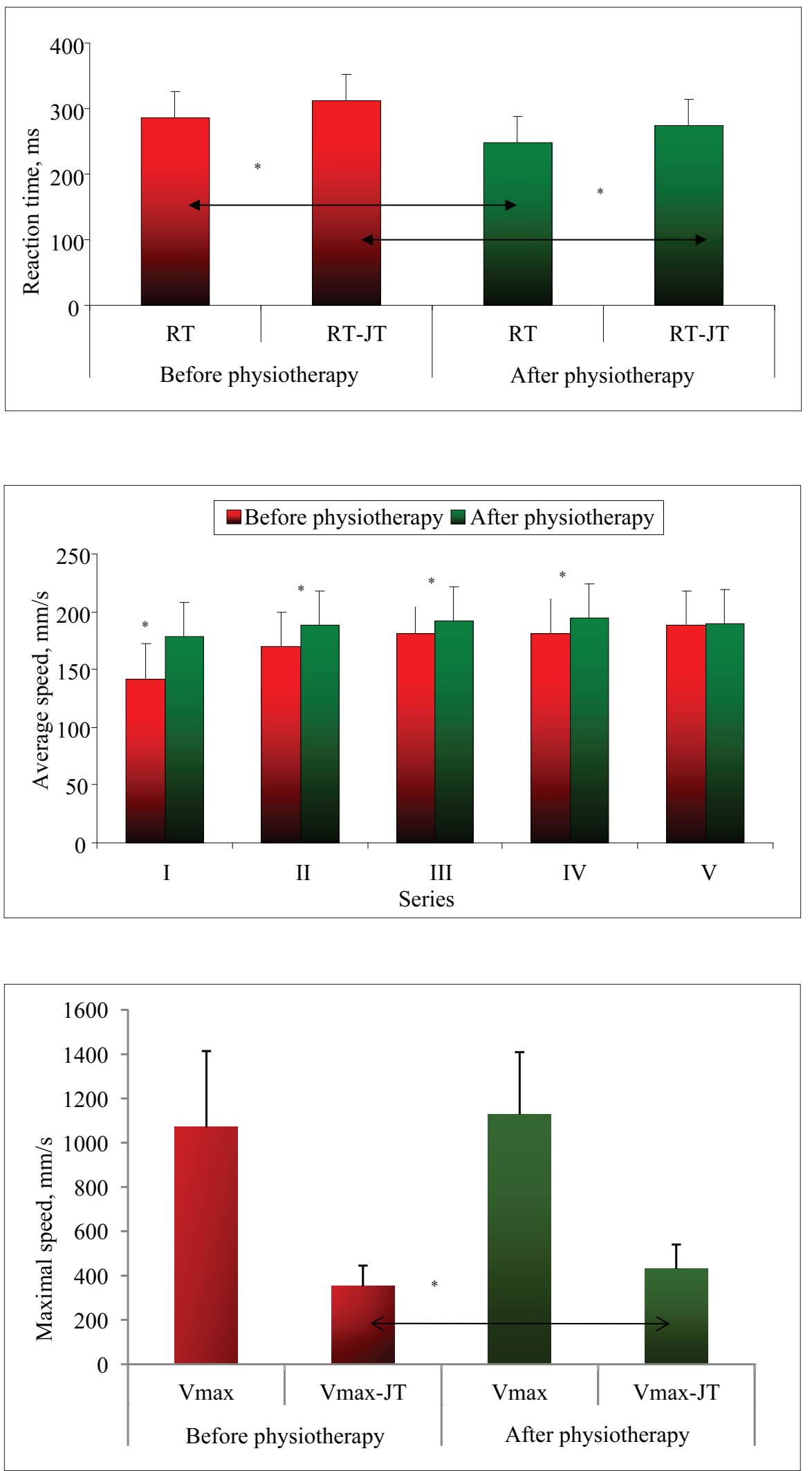

Figure 1. Reaction time (ms) averages in patients with Parkinson's disease performing a task of 5 sets of 20 repetitions before and after physiotherapy. RT-simple task, RT-JT-complicated task

Note. $*-p<0.001$, compared to the results before and after physiotherapy.

Figure 2. Average speed $(\mathrm{mm} / \mathrm{s})$ in patients with Parkinson's disease performing a task of 5 sets of 20 repetitions before and after physiotherapy

Note. ${ }^{*}-\mathrm{p}<0.001$, compared to the results before and after physiotherapy.

Figure 3. Maximal speed $(\mathrm{mm} / \mathrm{s})$ averagesin patients with Parkinson's disease performing a task of 5 sets of 20 repetitions before and after physiotherapy. Vmax -simple task, Vmax-JT -complicated task

Note. ${ }^{*}-\mathrm{p}<0.001$, compared to the results before and after physiotherapy. 
Figure 4. Averages of individual task performance results of Confidence in Balance Scale before and after physiotherapy
Note. $*-p<0.001$, compared to the results before and after physiotherapy.

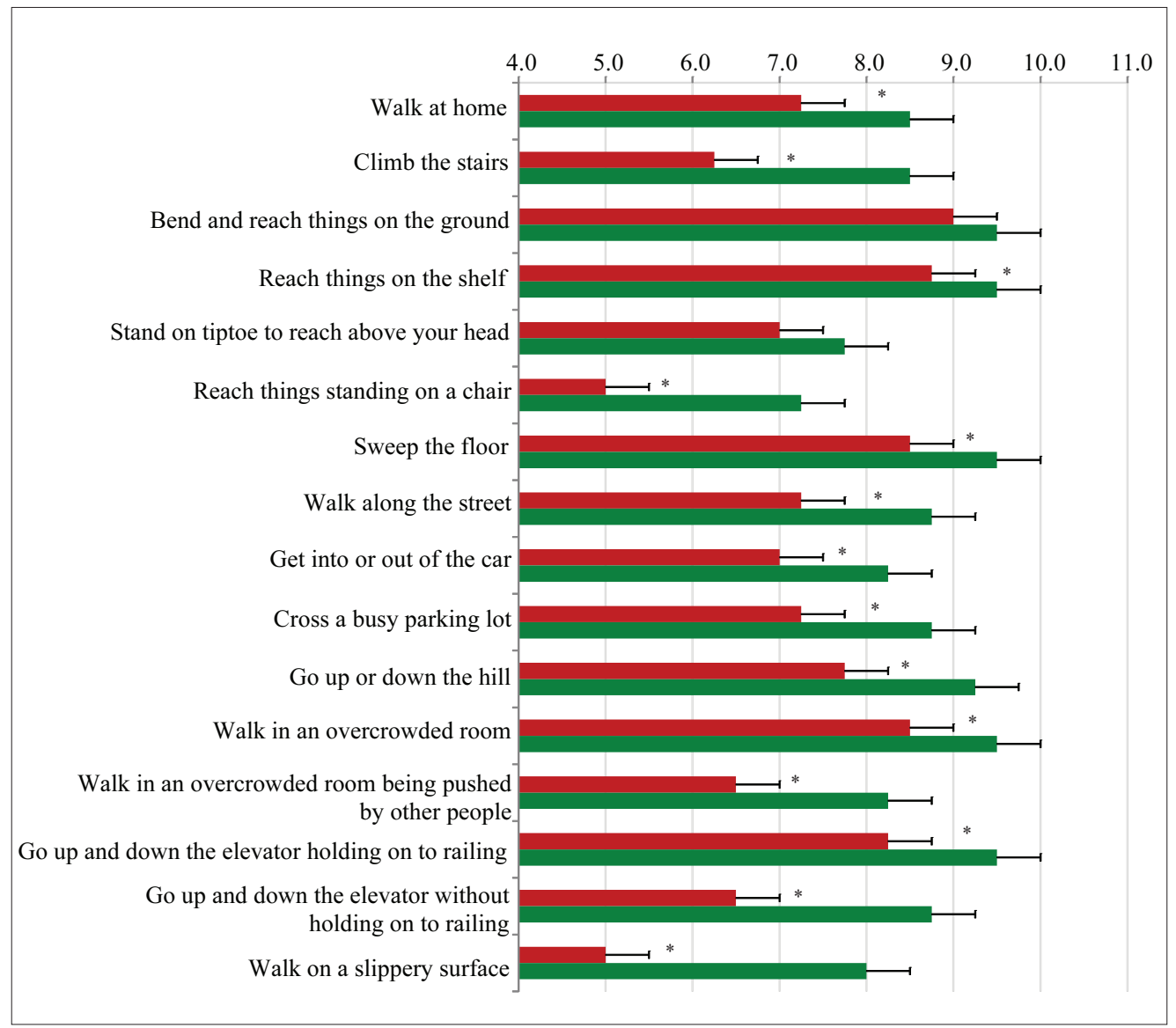

The results showed that physiotherapy for patients with $P D$ had a significant effect on reaction time $(p<0.001)$, the average speed of movement $(p<0.001)$, the maximum speed of movement $(\mathrm{p}<0.001)$ and balance $(\mathrm{p}<0.001)$.

While evaluating the maximum speed of movement before and after physiotherapy, a statistically significant difference was established in the accuracy of movement task ( $p<0.001)$, when after hearing the sound the participants had to respond as fast as possible and to hit the target as accurately as possible. In the simple task, when the subjects had to push the device handle when they heard the sound, no statistically significant change in the results of the maximum speed before and after physiotherapy has been established.

The overall mean result of the confidence in balance scale prior to the test was $7.23 \pm 1.21$ points. Prior to physiotherapy, worst of all (5 points) the subjects assessed their ability to maintain balance and preserve stability when they were going on a slippery surface, reaching for an object while standing on a chair. After the investigation the same two questions were rated the worst as well, but the results improved much. When they were asked if they trusted their ability to maintain balance and not lose stability when reaching for something standing on a chair, the result after physical therapy improved by $45 \%$. Their confidence in walking on slippery surfaces improved $60 \%$ after physiotherapy. After the investigation the overall average result of the scale of was $8.72 \pm 0.71$ points. Testing results of the balance scale, comparing the values before and after physiotherapy, improved by $20.52 \%$. At the end of the study, the subjects' balance statistically significantly improved $(\mathrm{p}<0.001)$.

\section{DISCUSSION}

Based on the obtained data we can claim that this is the first study that examines the effects of physiotherapy at home for patients with Parkinson's disease on their balance and the dynamic and kinematic characteristics of the dominant hand. The aim of the study was to assess the effect of home physiotherapy on balance and dynamic as well as kinematic movement characteristics of the dominant hand for people with Parkinson's disease. The main finding of our research was that physiotherapy proved to be an effective and reliable 
way for people suffering from Parkinson's disease to train their balance, as well as kinematic and dynamic characteristics of movements.

M. E. Morris (2000) argues that it is important to start physical therapy as soon as possible when Parkinson's disease diagnosis is established, due to muscle atrophy, weakness, and prevention of the loss of range of movement and physical fitness. Therefore, we chose patients with stages 1-2 of the disease for our research. E. E. Dereli and A. Yaliman (2010) state that physiotherapy treatments are much more effective in patients with Parkinson's disease when the therapist works with the patient at home compared to independent work at home using a special programme. J. Nocera and co-authors (2009) argue that home physiotherapy programmes for patients with Parkinson's disease are effective.

This was confirmed by our results. Our results suggest that physiotherapy at home is effective in patients with Parkinson's disease for training movement accuracy and speed. Movement speed and accuracy of our research participants significantly improved after 16 sessions of physiotherapy. D. Mickevičienè and co-authors' (2008) studies with healthy human subjects suggest that in a complex task reaction is slower, and the maximum speed of movement is lower than in a simple task. Movement speed will be higher when the reaction is faster in a simple task. We found the same trend in our study. Thus, in both healthy subjects and patients with Parkinson's disease, reaction time, movement speed and accuracy depend on the complexity of the task.

Performing the tasks of varying complexity, movement reaction time and movement speed of the right hand significantly differed before and after physiotherapy. M. E. Morris (2000) argues that every week practicing to perform taking tasks that require agility, accuracy and attention as well as concentration can maintain the required level of functionality. It is recommended to perform the task with a greater variety of different purposes, objects of different size or weight, different movement speed and the distance to the object.

In 2004 a stud was carried out which measured the short-term stimulating effects of music for persons with PD and with coordination problems. The results obtained show that the accuracy and walking a straight line improved; the accuracy of performance of the right hand improved as well. The results show that music can improve hand and finger movement accuracy (Bernatzky et al., 2004). We also used in physiotherapy music and got similar results. Our subjects also improved the accuracy of their right arm.

Summing up, physiotherapy proved to be an effective and reliable way for people suffering from Parkinson's disease to train their balance, as well as kinematic and dynamic characteristics of movements.

\section{CONCLUSIONS AND PERSPECTIVES}

1. After physiotherapy, coordination of patients with Parkinson's disease in the dominant hand significantly improved: reaction time became shorter, maximum and average speed of task performance increased.

2. After physiotherapy, balance for patients with Parkinson's disease significantly improved.

\section{REFERENCES}

Bernatzky, G., Bernatzky, P., Hesse, H. P., Staffen, W., Ladurner, G. (2004). Stimulating music increases motor coordination in patients afflicted with Morbus Parkinson. Neurosience Letters, 361 (1-3), 4-8.

Burton, F., De Girolamo, L., Harqreaves, A., Billett, E. E. (2011). Alterations in the mitochondrial proteome of neuroblastoma cells in response to complex 1 inhibition. Journal of Proteomne Research, 15, 6-11.

Danusevičienè, L., Ziblaitè, G. (2010). Žmoniu, sergančių Parkinono liga, patirtis. Sveikatos mokslai, 1, 2857-2863.

Dereli, E. E., Yaliman, A. (2010). Comparison of the effects of a physiotherapist-supervised exercise programme and a self-supervised exercise programme on quality of life in patients with Parkinson's disease. Clinical Rehabilitation, 24 (4), 352-362.

Kazlauskas, H. (2009). Sergančiuju Parkinsono liga slauga. Klaipèda: KU Leidykla.

Mickevičienè, D., Motiejūnaitè, K., Skurvydas, A., Darbutas, T., Karanauskienè, D. (2008). How do reaction time and movement speed depend on the complexity of the task? Ugdymas. Kūno kultūra. Sportas, 2 (69), 57-63.

Morris, M. E. (2000). Movement disorders in people with Parkinson disease: A model for physical therapy. Physical Therapy, 6 (80), 578-597.

Nocera, J., Horvat, M., Ray, C. (2009). Effects of home-based exercise on postural control and sensory 
organization in individuals with Parkinson's disease. Parkinsonism \& Related Disorders, 15 (10), 742-752.

Reinshagen, A. (2009). Morbus Parkinson (Paralysis agitans, Schüttellähmung). Medizin Netzam, 13, 17551824.

Weintraub, D., Comella, C., Horn, S. (2008). Parkinson's Disease-Part 1: Pathophysiology, Symptoms, Burden,
Diagnosis, and Assessment. The American Journal of Managed Care, 14, 40-48.

Wulf, G., Landers, M., Lewthwaite, R., Töllner, T. (2009). External focus instructions reduce postural instability in individuals with Parkinson disease. Physical Therapy, 89, 162-168.

\title{
KINEZITERAPIJOS NAMUOSE POVEIKIS SERGANČIǓJŲ PARKINSONO LIGA PUSIAUSVYRAI IR DOMINUOJANČIOS RANKOS DINAMINE்MS BEI KINEMATINE்MS JUDESIO YPATYBËMS
}

\author{
Dalia Mickevičienė ${ }^{1}$, Indrẻ Skirmantaitė ${ }^{1,2}$, Albertas Skurvydas ${ }^{1}$, \\ Diana Karanauskiené ${ }^{1}$, Aiva Karpavičienè ${ }^{1}$ \\ Lietuvos sporto universitetas ${ }^{1}$, Kaunas, Lietuva \\ Mykolo Romerio universitetas ${ }^{2}$, Vilnius, Lietuva
}

\section{SANTRAUKA}

Tyrimo pagrindimas ir hipoteze. Parkinsono liga (PL) - vyresniojo amžiaus žmonių susirgimas, pasireiškiantis motoriniais simptomais (drebuliu ramybèje, bradikinezija, rigidiškumu, posturaliniu nestabilumu) trūkstant dopamino organizmo ekstrapiramidinejje sistemoje. Tyrimais nustatyta, kad kineziterpija kartu su PL gydymu iprastai vartojamais vaistais gali sulètinti vis didejjantị nejudrumą.

Tikslas - îvertinti kineziterapijos namuose poveiki sergančiujų PL pusiausvyrai, dominuojančios rankos dinaminèms ir kinematinèms judesio ypatybèms.

Metodai. Tiriamuju grupę sudarè 8 ligoniai, sergantys 1-2 PL stadija, ligos požymiai-dešinėje rankoje. Tyrimas atliktas naudojant Fullerton pusiausvyros testą bei rankų ir kojų judesių dinaminių rodiklių analizatorių DPA-1.

Rezultatai. Sergančiujų PL pusiausvyra, judesių kinematinès ir dinaminės ypatybės po kineziterapijos pratybų namuose ciklo statistiškai reikšmingai pagerejo $(\mathrm{p}<0,05)$.

Aptarimas ir išvados. Po kineziterapijos sergančiujų PL dominuojančios rankos koordinacija reikšmingai pagerejo: sutrumpejjo reakcijos laikas, padidejo maksimalusis ir vidutinis užduoties atlikimo greitis, statistiškai reikšmingai pagerejo pusiausvyra. Tyrimo rezultatai parode, kad kineziterapija namuose yra veiksmingas ir patikimas būdas gerinant sergančiujų PL pusiausvyrą, lavinant judesių kinematines ir dinamines ypatybes.

Raktažodžiai: kineziterapija, Parkinsono liga, judesių greitis ir tikslumas, reakcijos laikas.

Gauta 2013 m. sausio 15 d.

Received on January 15, 2013 